\title{
ERDEI ROVAROK REAKCIÓI A KLÍMAVÁLTOZÁSRA (ESETTANULMÁNYOK)
}

\author{
Csóka György¹, Hirka Anikó1, Csepelényi Mariann², Szőcs Levente", Molnár Miklós³, \\ Tuba Katalin ${ }^{3}$, Hillebrand Rudolf ${ }^{3}$ és Lakatos Ferenc ${ }^{3}$
}

${ }^{1}$ NAIK Erdészeti Tudományos Intézet, Erdővédelmi Osztály

${ }^{2}$ Szent István Egyetem, MKK Növényvédelmi Intézet

${ }^{3}$ Soproni Egyetem, Erdőmüvelési és Erdővédelmi Intézet

\begin{abstract}
Kivonat
A rovarok és környezetük kapcsolata rendkívül szoros, ezért ha abban - például a klímaváltozás miatt - a legkisebb változás is bekövetkezik, arra érzékenyen reagálnak. Ez a reakció igen változatos lehet. Megváltozhat elterjedési területük, megváltozhat fejlődési idejük és ezen keresztül a generációs viszonyaik, illetve a populáció nagyságát befolyásoló tényezők (természetes ellenségek, mortalitás) hatása is eltérhet. Külön ki kell emelni a növényevő rovarok és gazdanövényeik közötti érzékeny kölcsönhatást, ahol a gazdanövényben bekövetkezett változásra (pl. szárazság, vagy hőség által kiváltott stressz) rendkívül gyorsan képesek a rovarok reagálni. Végeredményképpen új fajok jelenhetnek meg, korábban ritka fajok tömegszaporodása következik be, illetve növekedhet kártételi területük. Az elmúlt évtizedekben bekövetkezett változásokat hat mintapéldán keresztül mutatjuk be: tölgy csipkéspoloska (Corythucha arcuata), májusi cserebogár (Melolontha melolontha), tölgy búcsújáró lepke (Thaumetopoea processionea), gyapottok bagolylepke (Helicoverpa armigera), gyapjaslepke (Lymantria dispar), illetve a lucfenyvesekben bekövetkezett szúkártétel.
\end{abstract}

Kulcsszavak: tölgy csipkéspoloska, májusi cserebogár, tölgy búcsújáró lepke, gyapottok bagolylepke, gyapjaslepke, szúkártétel, klímaváltozás.

\section{RESPONSE OF FOREST INSECTS TO THE CLIMATE CHANGE (CASE STUDIES)}

\begin{abstract}
There is a very tight relationship between insects and their environment, therefore if there is even the slightest change due to climate change for instance, they react sensitively. This reaction can be very diverse. Their area can expand, their development time can change and consequently their number of generations can alter as well. Effect of factors influencing the size of the populations (natural enemies, mortality) can differ too. It should also be mentioned the sensitive interaction between herbivore insects and host plants in particular, where the insects can react very fast to the changes in the host plant (e.g. drought, stress caused by heat). Ultimately new species can appear, previously rare species can have mass outbreaks or their damage area can expand. We are demonstrating the changes of the last decades in six sample examples: oak lace bug (Corythucha arcuata), cockchafer (Melolontha melolontha), oak processionary moth (Thaumetopoea processionea), cotton bollworm (Helicoverpa armigera), gypsy moth (Lymantria dispar), in addition to the bark beetle damage in spruce stands.
\end{abstract}

Keywords: oak lace bug, cockchafer, oak processionary moth, cotton bollworm, gypsy moth, bark beetle damage, climate change. 


\section{BEVEZETÉS}

A rovarok fokozottan ki vannak téve a környezeti tényezőknek, illetve azok változásainak, így a klíma is számos direkt és indirekt módon befolyásolja őket (Csóka 1996, 1997, Lakatos \& Molnár 2009, Molnár et al. 2010, Robinet \& Roques 2010, Pureswaran et al. 2018, Csóka et al. 2018). A klímában bekövetkező változások hatással vannak például egyes rovarfajok elterjedési területének alakulására (Vanhanen et al. 2007, Battisti 2008, Jepsen et al. 2008, Battisti \& Larsson 2015, Battisti et al. 2017). A változó klíma növelheti, esetleg csökkentheti egyes többnemzedékes rovarfajok éven belüli generációinak számát (Ayres \& Lombardero 2000, Jönsson et al. 2009). A téli időjárási viszonyok az elszenvedett telelési mortalitás okán meghatározóak lehetnek egy faj megtelepedésében és népességének alakulásában (Csepelényi et al. 2017a). A klíma hatással van a rovarok és tápnövényük (Pelini et al. 2009, Robinet \& Roques 2010), illetve a rovarok és természetes ellenségeik interakcióira (Jeffs \& Lewis 2013, Kalinkat \& Rall 2015). Ezen különböző jellegü hatások eredője sok esetben tömegszaporodásokat, ezen keresztül pedig jelentős gazdasági károkat, illetve ökológiai hatásokat is okozhatnak. Ezt meglehetősen sok tanulmány taglalja is (Mattson \& Haack 1987, Leskó et al. 1995, 1998, Csóka 1997, Rouault et al. 2006, Dobbertin et al. 2007, Jactel et al. 2012, Klapwijk et al. 2013, Hlásny et al. 2015, Pureswaran et al. 2018).

Az utóbbi három évtized során lucosaink területe drámai mértékben csökkent. Bár a tömeges magyarországi lucpusztulás közvetlen okozói jellemzően a szúbogarak (föként a betüzőszú - Ips typographus), az időjárás elsődleges hatása itt is megkerülhetetlenül felmerül. A gyakoribb vihar- és hókárok tömeges költöhelyet biztosítanak a szúknak, az enyhe telek, aszályos tavaszi, nyári időszakok pedig gyorsabb fejlődést (esetenként több nemzedéket) és kisebb mortalitást eredményeznek. Számos további rovarkár vonatkozásában is nyilvánvaló összefüggés mutatható ki az időjárási viszonyokkal (Csóka 1996, 1997, Csóka et al. 2018). Két-három aszályos évet követően növekszik az erdei rovarkárok területe. Az évezred első néhány évének súlyos aszályai egyértelműen segítették a gyapjaslepke eddig regisztrált legnagyobb tömegszaporodásának, illetve kárterületének kialakulását. Ez a tömegszaporodás nemcsak, hogy a korábban tapasztaltaknál jóval nagyobb területü volt, de vertikálisan is kiterjedt, azaz nemcsak a megszokott sík- és alacsony dombvidéki lombos állományokban, hanem hegyvidéki bükkösökben is jelentkezett (Csóka \& Hirka 2009). A lombvesztést szenvedett bükkök regenerációja jóval lassabb és kevésbé teljes körü, mint pl. a csereké. A lombvesztés a bükkök esetében hosszabb távon is egészségi állapot romlást eredményezhet (Csóka et al. 2015).

A korábbról jól ismert erdei rovarfajok növekvő kártrendjein (Hirka et al. 2011; Klapwijk et al. 2013;) túl egyre több olyan kárformával kell szembesülnünk, amikkel korábban nem, vagy csak igen ritkán találkozhattunk (Lakatos \& Molnár 2009, Molnár et al. 2010, Hirka \& Csóka 2010, Csóka 2016).

Az európai, így a magyar erdökben is gyorsuló ütemben jelennek meg idegenhonos rovarfajok (Turcani et al. 2001, Csóka 2001, Csóka et al. 2012, Szeőke \& Csóka 2012, Tuba 
et al. 2012). Az utóbbi 2 évtizedben több új fajt regisztráltak, mint az azt megelőző 110 évben. Habár ezért a trendért nem elsősorban a klímaváltozás okolható, a jelenség klimatikus vonatkozásai számos esetben nyilvánvalóak. Természetesen nem minden jövevény faj válik invázióssá, de közülük több, jelentős kárpotenciállal bír.

A klímaváltozás rovarokra gyakorolt hatásainak alaposabb megismerése tudományos érdekességén túl számottevő gyakorlati jelentőséggel is bír. Megbízható, hosszú távú előrejelzéseket ugyanis csak érdemi kutatási eredményekre alapozva lehet tenni. A jövőbeni kockázatokat csökkentő döntéseket, beavatkozásokat pedig érdemi elörejelzések híján nehéz elképzelni.

Jelen tanulmányban néhány, föként hazai kutatási eredményekre alapozott esettanulmányt ismertetünk, arra vonatkozóan, hogy a klímaváltozás miként befolyásolhatja egyes rovarfajok elterjedését, népességük alakulását, ezen keresztül pedig erdészeti jelentőségét.

\section{Tölgy búcsújáró lepke [Thaumetopoea processionea (Linnaeus, 1758)]}

A búcsújáró lepkék (Lepidoptera: Notodontidae), különösen a fenyő búcsújáró lepke (Thaumetopoea pityocampa (Denis \& Schiffermüller, 1775)) az utóbbi időben jelentős figyelmet vívtak ki a klímaváltozással magyarázható area expanziójuknak köszönhetően (Pimentel et al. 2006, 2011, Hoch et al. 2009, Straw \& Williams 2013, Roques et al. 2015, Mirchev et al. 2016). A genusz másik, jelentős terjeszkedést mutató faja a nálunk is honos tölgy búcsújáró lepke. A faj Délkelet-Európában a tölgyek időnként és helyenként tömegesen fellépő, jól ismert lombfogyasztója. Csalánzó hernyószőrei miatt jelentős humán-egészségügyi jelentőséggel is bír. Az utóbbi néhány évtizedben figyelemre méltó nyugati, északnyugati irányú terjeszkedést mutatott (Groenen 2010, Groenen \& Meurisse 2012). 65 év „szünet” után, 1970-ben újra előkerült Belgiumból (Groenen 2010), 100 év kihagyás után pedig Hollandiából (Stigter \& Romeijn 1992). Szintén 100 év elteltével észlelték újra ÉszaknyugatLengyelországban (Blaik et al. 2011). Ezeket a folyamatokat ugyan inkább rekolonizációnak, mintsem tényleges area expanziónak tartják (Groenen \& Meurisse 2012), ugyanakkor a faj hím egyedeit fogták már Dániában (Skule \& Vilhelmsem 1997) és Svédországban is (Lövgren \& Dalsved 2005), ahol korábban még soha nem jegyezték fel őket. Megjegyzendő, hogy a nemzetközi kereskedelem szintén közrejátszhat a terjeszkedésben. Ennek köszönhető pl. a faj megjelenése az Egyesült Királyságban is (Baker et al. 2009, Mindlin et al. 2012).

A faj egynemzedékes, pete alakban telel, fö tápnövénye a cser, de más tölgyeken is megél. Hernyói május-júniusban rágnak, a lepkék júliustól szeptemberig repülnek, de akár még decemberben is lehet élő lepkéket találni. Éves átlagos kárterülete Magyarországon (1961-2012) 808 ha, de az utóbbi két évtized egyes éveiben ennél jóval nagyobb kárterületeken lépett fel, 2004-ben országosan 4270 ha-ról jelentették kártételét, ami a kárjelentések bő fél évszázadának legnagyobb kárterülete volt (Csóka et al. 2018). 
Egy közelmúltban megjelent tanulmány (Csóka et al. 2018) három nyugat-magyarországi fénycsapda éves fogásainak alakulását elemzi az időjárási viszonyokkal való összefüggésben. Fő megállapítása, hogy a lárvastádium időjárási viszonyai meghatározóan befolyásolják a faj népességét. A májustól júliusig terjedő időszak átlagos hőmérséklete pozitívan, ugyanezen időszak csapadékösszege pedig negatívan befolyásolja az adott évi fogási számokat. Ez egyben azt is jelenti, hogy a faj népességének és kárterületének növekedésére kell számítanunk, amennyiben a jelzett időszakok egyre melegebbek és csapadékszegényebbek lesznek. A tavaszi időjárás népességre gyakorolt hatásáról (adatokra alapozott elemzések nélkül) egyébként már többen is említést tesznek (Klapwijk et al. 2013, Wagenhoff \& Veit 2011, Wagenhoff et al. 2013, 2014).

\section{Gyapottok bagolylepke [Helicoverpa armigera (Hübner, 1808)]}

Habár a jövevény fajok egyre gyakoribb megjelenésének föként a rohamosan növekvő volumenű világkereskedelem a fő mozgató rugója (Vanhanen et al. 2008, Tuba et al. 2012, Csóka et al. 2012), sok esetben a klímaváltozás hatásai is tetten érhetőek. Látványos példát szolgáltat erre vonatkozóan a gyapottok bagolylepke. Melegigényes, trópusi/mediterrán, vándorlepke faj (Tuba et al. 2012), 1986 előtt Magyarországon kifejezetten ritkának számított. Az Erdészeti Fénycsapda Hálózat csapdái müködésük első negyed századában mindösszesen hat példányát fogták. Ezt követően azonban egyre gyakrabban került a fénycsapdákba, az utóbbi három évtizedben a csapdák növekvő számban fogják, néhány csapda egyes években több ezres egyedszámban. A vándor lepkefajok, így a gyapottok bagolylepke is, egyre gyakrabban jelennek meg nagyobb tömegben, és honosodnak meg az északi táplálkozási területeiken (Sparks et al. 2005). Az egyre gyakrabban jelentkező aszályok általában segítik tömegszaporodásait (Szabóky \& Szentkirályi 1995). A gyapottok bagolylepkének több, egymást jelentősen átfedő nemzedéke lehet. Rendkívül polifág. Az utóbbi két évtizedben jelentős mezőgazdasági (kukorica, napraforgó, paradicsom, alma, stb.) kártevővé vált, de akác, nemes nyár és tölgy fiatalosokban is észlelték már kártételét (Leskó \& Szabóky 2003, Keszthelyi et al. 2013). Megjegyzendő, hogy világszerte jelentős kártevőként tartják nyilván. A népességnövekedés mellett figyelemre méltóak a rajzásfenológiában bekövetkező változások is. Az első példányokat egyre korábban fogják az Erdészeti Fénycsapda Hálózat csapdái, így a fogási súlynap szintén egyre korábbra tevődik (Szőcs et al. kézirat). Ez a meghosszabbodott tenyészidőszak magában hordozza több nemzedék kifejlődésének lehetőségét, ezáltal pedig a kárpotenciál növekedését is. 


\section{Tölgy-csipkéspoloska [Corythucha arcuata (Say, 1832)]}

Az észak-amerikai származású inváziós tölgy-csipkéspoloska (Corythucha arcuata Say, 1832) első európai észlelése Észak-Olaszországból származik (Bernardinelli \& Zandigiacomo 2000). 2002-ben Törökországban (Mutun 2003), 2005-ben Svájcban (Forster et al. 2005) is elökerült. 2013-ban, közel egy időben megtalálták Bulgáriában (Dobreva et al. 2013), Horvátországban (Hrašovec et al. 2013) és Magyarországon (Szarvas) is (Csóka et al. 2013). Később több más európai országban is megjelent. Magyarországi, robbanásszerű terjeszkedését Csepelényi et al. (2017b) foglalták össze.

A faj kifejlett stádiumban, kéreg alatt, kéregrepedésekben, ágvillákban telel. Valószínűsítettük, hogy a váratlan tömegszaporodás egyik előmozdítója a megelőző három, rendkívül enyhe tél, illetve az ezeknek köszönhető alacsony telelési mortalitás volt. Ugyanakkor az is feltételezhető volt, hogy a 2016/2017-es, a korábbi háromnál jóval keményebb tél, jelentős veszteségeket okozhatott a telelő populációkban. Ez utóbbi feltételezésünk tisztázása érdekében öt helyszínen (Békéscsaba, Gyula és Szarvas, Tiszakürt, Tőserdő) célirányos telelési mortalitási vizsgálatokat végeztünk (Csepelényi et al. 2017a). A március végén begyüjtött 4770 telelő egyed 63,5\%-a sikeresen átvészelte a telet. Azaz várakozásunkkal ellentétben a viszonylag kemény tél sem okozott számottevő telelési mortalitást. Ezt erősíti az a tény is, hogy a faj 2017-ben Magyarországon, de a környező országok némelyikében is jelentős expanziót és tömegszaporodásokat mutatott. Mivel az Európában honos tölgyfajok túlnyomó részben megfelelő tápnövényt jelentenek a csipkéspoloskának, további terjeszkedése várható.

A tölgy csipkéspoloskával kapcsolatban egyelöre nyilvánvalóan több a megválaszolatlan kérdés, mint a tudományos megalapozottságú, megbízható ismeret. A teljesség igénye nélkül néhány fajsúlyos kérdés: A hosszabb időszakon át ismétlődő tömeges fellépései hogyan fognak hatni a fák növekedésére és egészségi állapotára? Befolyásolja-e a tömeges jelenlét a tölgyek makktermését, ezáltal a természetes felújitások, illetve a szaporítóanyag termelés lehetőségeit? A tömegessé váló inváziós faj miként fog hatni a tölgyeken élő fajgazdag specialista rovar együttesekre (köztük számos védett fajra)? Van-e (lesz-e) olyan természetes ellensége, illetve kórokozója, ami a populációit szabályozni képes? A kérdések megválaszolására csak érdemi, célirányos kutatásokat követően van esély.

\section{Májusi cserebogár [Melolontha melolontha (Linnaeus, 1758)]}

A Melolonthidae család a Kárpát-medencében 81 fajjal képviselteti magát (Endrődi 1956), melyekböl 11 rendelkezik erdőgazdasági jelentőséggel. Közöttük a májusi cserebogár (M. melolontha) kártétele kiemelkedő (Janik et al. 2008). Észak- és Közép-Európában a mérsékelt klímájú területeken mindenhol előfordul, de megtalálható Ázsiában és Kis-Ázsiában is. Magyarországon általánosan elterjedt. Leginkább a jól felmelegedő, középkötött barna erdőtalajokon fordul elö, de a homokos talajokon is tömegessé válhat, különösen a 
melegebb éghajlatú vidékeken. Az idők során a Kárpát-medencében a fajnak 7 törzse alakult ki. A hűvösebb, hegyvidéki területeken (Kárpátok) a négyéves fejlödésű, míg a melegebb sík és dombvidéki területeken a hároméves fejlődésü törzsek találhatók meg.

Az elterjedést, a rajzást és a pajorok túlélését alapvetően befolyásolják a klímatikus feltételek. Az imágó április végén, május elején bújik elő. A rajzás kezdete a kritikus időjárási paraméterek folyamatos mérésével elörejelezhetö, melyre több módszer is ismert (Tóth 1976, Nowinszky \& Nagy 1977, Bognár \& Huzián 1979, Hirka 2012). A hőmérséklet és csapadékviszonyok a rajzó nemzők mozgását, a peterakások számát, de a petézőhely kiválasztását is befolyásolják (Homonnay 1977, Bognár \& Huzián 1979). A peteállapot a talaj hőmérsékletétől és nedvességtartamától függően 32-50 napig tart. A peték, és később a fiatal lárvák egyaránt érzékenyek a talaj kiszáradására és a túl magas nedvességtartalmára, ezért a rajzás utáni június-július hónapok időjárása nagy jelentőséggel bír a populáció alakulásában. Az idősebb pajorok már szívósabbak, a szélsőségekre függőleges irányú mozgással reagálnak (Bognár \& Huzián 1979, Győrfi 1954). A klímatikus tényezők függvényében időrőlidőre változhat az egyes törzsek elterjedési és kártételi területe.

Az Erdészeti Tudományos Intézet Erdővédelmi Osztálya 1962 óta ad ki erdővédelmi prognózist. Az előrejelzés alapja már kezdetektől az erdővédelmi figyelő- és jelzőszolgálati rendszer, melynek keretein belül az erdőgazdálkodók közvetlenül a saját kezelésükben lévő erdőállományokban tapasztalt káreseményeket jelentik a központi nyilvántartás részére. Az Agrárklíma 2. projekt keretében feldolgoztuk az 1983-1997 időszakban a májusi cserebogár rajzásáról térképeken is közreadott gazdálkodói jelentéseket. A térképeket térinformatikai eszközökkel összehasonlítottuk a szakirodalomban még napjainkban is széles körben hivatkozott, 1973-ban publikált adatokkal (Homonnay 1973). A gazdálkodói jelentéseket összehasonlítottuk a korábban már feldolgozott Erdészeti Fénycsapdahálózat 2006-2016 közötti fogási adataival, melyek alapján a törzsek területének változásáról szereztünk információkat. Az V. törzs elterjedési területe az erdőgazdálkodók kárjelentései és a fénycsapda fogási adatok alapján kiterjedtebb, a szakirodalomban fellelhető elterjedési területnél. A VI. törzs elterjedési területe a vizsgált időszakban némileg csökkent. A VII. törzs előfordulása továbbra is szigetszerü, azonban egyre több új helyen figyelik meg a rajzását, illetve kártételét.

\section{Gyapjaslepke [Lymantria dispar (Linnaeus, 1758)]}

A gyapjaslepke (Lymantria dispar L. 1758) a mérsékelt övi lombos erdők egyik legfontosabb és legveszélyesebb erdészeti károsítója. A kárterülete tömegszaporodása esetén igen jelentős lehet. Legutóbbi magyarországi gradációja során (2003-2006) a szaporodás csúcsévében (2005) a károsított terület meghaladta a 200000 ha-t (Csóka \& Hirka 2009). Tömegszaporodását az időjárási körülmények, illetve a változó klíma hatásai is jelentősen befolyásolják. A kedvezőtlen környezeti tényezők ezekkel a hatásokkal, mint a száraz évek sorozata, a kiegyenlítetlen, kedvezőtlen eloszlású csapadék, összeadódva kedvező alapot biztositanak a gyapjaslepke zavartalan és tömeges fejlödésének (Csóka 1996). 
A klímaváltozással kapcsolatban, de attól függetlenül is a hömérséklet emelkedésének a gyapjaslepke fejlődésére gyakorolt hatásaival már több kutatás is foglalkozott. A hőmérséklet hatását a gyapjaslepke tojásokra többen is vizsgálták, míg az eredményeket végül egy szimulációs modellben próbálták egyesíteni (Sawyer et al. 1993, Gray et al. 1995). Mint jelentős környezeti hatással bíró, inváziós fajnak Észak-Amerikában, összefüggésben a klímaváltozással, modellezték lehetséges elterjedési határait. Az alkalmazott szimulációs modell segítségével, a hőmérséklet lehetséges emelkedéséhez kapcsolódó elterjedési terület változást is becsülték (Allen et al. 1993, Gray 2004). Laboratóriumi kísérletek során azt tapasztalták, hogy viszonylag magas hömérsékleten $\left(27^{\circ} \mathrm{C}\right)$ nevelt gyapjaslepke hernyók, még a rövid ideig tartó napi hőmérsékleti stressz $\left(1\right.$ óra, $\left.47^{\circ} \mathrm{C}\right)$ hatásra is színbeli elváltozással, méghozzá sötétedéssel, reagáltak. Ugyanez a hőstressz a lárvák fejlődési idejét lerövidítette, míg súlygyarapodását megnövelte. Azonban a höstresszek napi ismétlődése a súlygyarapodás tekintetében rövidesen visszaesést eredményezett (Ponomarev et al. 2014). A vizsgálatok többsége azt is igazolta, hogy a magasabb hőmérsékleti értékek a lárvakori fejlődést felgyorsítják (Gray 2004). Ugyanakkor a prediapauza, diapauza és posztdiapauza arányát is megváltoztatják (Gray et al. 2001).

A VKSZ Agrárklíma projekt keretében meghatároztuk a gyapjaslepke esetleges gazdanövény váltásának hatásait a faj egyedfejlődésére. Ennek során csertölgyön (Quercus cerris), gyertyánon (Carpinus betulus), pannon nyáron (Populus x euramericana Pannonia) és mesterséges tápanyagon $(A D)$ neveltünk gyapjaslepke hernyókat a tojásból való kikeléstől a lepke kifejlődéséig (30-30 egyed, 16:8 nappal:éjszaka, illetve $20^{\circ} \mathrm{C}$ hömérséklet mellett). Két esetben a nevelés során tápnövényt is váltottunk (cserröl gyertyánra).

A hernyók mortalitásának mértéke a mesterséges tápanyagon volt a legalacsonyabb $(0 \%)$, illetve a váltott tápnövényen (cserröl gyertyán) a legmagasabb (30\%). A bábok esetében hasonló volt a kép, bár a legmagasabb mortalitást a tisztán gyertyánon nevelt egyedek eseteben tapasztaltuk. A fejlödési idő hossza is jelentős mértékben függött az ezalatt kapott táplálék minőségétől. A gyapjaslepke hernyók fejlődési paraméterei azonban nem csupán a mortalitási rátában, illetve a fejlődési időben különböztek, attól függően, hogy milyen táplálékkal etettük öket, hanem a tömeggyarapodás mértékében is. A már korábban is ismert tényen túl - azaz a nőstény hernyók tömeggyarapodása többszöröse (2-4-szerese) a hím hernyók tömeggyarapodásának - egyértelmü különbséget mutattak a különböző gazdanövényen nevelt hernyók. Különösen igaz ez a nőstény egyedek esetén, ahol a peteprodukció nagy mértékben függ a hernyó állapotban felvett táplálék mennyiségétől.

A kapott adatok jól mutatják egy erősen polifág lombfogyasztó rovar, a gyapjaslepke plaszticitását. A változó környezet miatti esetleges gazdanövény váltás hatásai nem írhatók le egyetlen jellemzővel. A végső hatást a különböző tulajdonságok (mortalitás, fejlődési sebesség, tömeggyarapodás, stb.) változásának összessége adja meg. 


\section{Szúkártétel a hazai lucosokban}

Nagyságrendjét és jelentőségét tekintve a lucosokban bekövetkezett szúkártétel az elmúlt időszak legjelentősebb, klímaváltozással összefüggésbe hozható erdővédelmi problémája volt mind Európában (Hlasny \& Turcani 2008, Netherer et al. 2014, Marini et al. 2017, Pureswaran et al. 2018) mind hazánkban (Győrfi 1950, Jurásek \& Román 1997, Lakatos 1997, Roth 2003, Szép 2005, 2008).

A szúbogarak Magyarországon már a II. világháború után (1946-48) is okoztak jelentékeny károkat. Ekkor például a soproni lucosok 1/6-át, mintegy $70000 \mathrm{~m}^{3}$ faanyagot termeltek ki (Győrfi 1963). Az itteni tapasztalatok alapján vezettek be olyan intézkedéseket, mint a tisztítási faanyag megsemmisítésének finanszírozása, akkor még az erdőfenntartási alapból. Az évek során azonban a károsítás tapasztalatai feledésbe merültek, sőt még az intézkedéseket is eltörölték. A 80-as évek elejétől kezdve újból jelentkezett szúkártétel a hazai lucfenyvesekben, de ezek elszórtan fordultak elő, és mennyisége ritkán haladta meg a néhány 100 m³-t. Jelentősebb kárositás 1991-töl jelentkezett ismét, elöször a Soproni-hegyvidéken, majd a Kőszegi-hegységben, illetve az Örség és Zala lucfenyveseiben. A kártétel hullámokban jelent meg, és többnyire összefüggésbe volt hozható a száraz meleg nyári idöjárással. A szúkártétel és a klímatikus tényezök közötti összefüggések pontos, statisztikai elemzését megnehezítette a kártételröl rendelkezésre álló adatok pontatlansága. Mind a kitermelt faanyag mennyiségét, mind az érintett terület nagyságát tekintve változó pontosságú adatok álltak rendelkezésre. A végrehajtott fahasználatok több esetben nem egészségi termelés címszó alatt, hanem más használati kategóriába sorolva történtek (pl. véghasználat).

A szúkárositás ilyen jelentős mértéke több okra is visszavezethető, melyek együttes fellépése tovább súlyosbította a helyzetet:

1. Klímaigény: A lucfenyő hegyvidéki fafaj, $1000 \mathrm{~m}$ tengerszint feletti magasságban öszszefüggő állományokat alkot. Bár a Soproni- és Kőszegi-hegységben őshonos előfordulása vitatott, Magyarországon klímaigényének megfelelő terület nem, vagy csak nagyon korlátozottan található. Ennek ellenére igen kedvelt fafaj volt, hiszen növekedése gyors, a vad kevésbé szereti, és még extrém termőhelyeken is jó növekedést mutat. Gazdaságossági szempontok is csak alátámasztották telepítését.

2. Túltartottság: Alacsonyabb hegy- és dombvidéki régiókban csak alacsonyabb vágásérettségi korral lehet a lucfenyveseket fenntartani. Különösen veszélyes az eredetileg tervezett vágáskor kitolása valamilyen ürüggyel (pl. természetvédelem).

3. Gyors reagálás hiánya: Fenyvesekben mindig kiemelt figyelemmel kell kísérni a szúbogarak jelenlétét és megjelenését. Elegendő egy két-három fából álló „szúfolt” figyelmen kívül hagyása, és a tenyészidőszak végére már akár hektáros nagyságrendet is elérhet a pusztulás.

4. Klímaváltozás - gyakoribb abiotikus káresemények, száraz, meleg periódusok: Már az előzőekben felsorolt pontok is elegendő feltételt biztosítottak volna a szúkárositás növekedéséhez, de az utóbbi évtizedekben bekövetkezett, klímaváltozásra visszavezethető ese- 
mények is jelentősen felerősitették a negatív trendeket. Az egyre gyakoribb és nagyobb területet érintő abiotikus kalamitások (viharkárok, hótörés, stb.) és súlyos aszályok egyaránt elősegítették a szúk tömeges fellépését, ezzel pedig a lucosok általános egészségi állapotának jelentős romlását. Saját, publikálatlan elemzéseink szerint az aszályosság jelentős, statisztikailag is szignifikáns hatással van a bejelentett szúkárok területére.

A lucfenyvesekben bekövetkezett pusztulás során a legfontosabb károsító a betűzőszú (Ips typographus) volt, de a kéreg alatt megtalálhatók voltak a rézmetszőszú (Pityogenes chalcographus) és a firkáló fenyőszú (Polygraphus poligraphus) menetei is.

Jól mutatja a klímaváltozás hazai lusosokra gyakorolt hatását, hogy a Soproni-hegyvidék lucfenyveseinek területe az 1990-es évek elején még 1000 ha volt, ami a töredékére (250 ha) csökkent. Jelentősen átalakult a faállomány szerkezet (a lombos fafajok javára) és ezzel együtt a gazdálkodás is. A bekövetkezett változások egy klímaváltozás hatására induló, és különböző károsítók (föként szúbogarak) által befejezett pusztulási folyamat tipikus példája. A teljesség kedvéért megemlítendő azonban, hogy a luc magyarországi területfoglalásának csökkenése részben természetvédelmi korlátozásokra is visszavezethető. Védett területeken ugyanis a luc „nemkívánatossá” vált, így a letermelt lucosok helyén jellemzően más fafajokkal történik meg az újraerdősítés.

\section{KÖSZÖNETNYILVÁNÍTÁS}

Jelen tanulmány elkészítését a VKSZ_12-1-2013-0034-Agrárklíma.2 projekt támogatta.

\section{FELHASZNÁLT IRODALOM}

Allen J.C., Foltz J.L., Dixon W.N., Liebhold A.M., Colbert J.J., Regmere J., et al. 1993: Will the gypsy moth become a pest in Florida? The Florida Entomologist 76(1): 102-113. DOI: 10.2307/3496018

Ayres M.P. \& Lombardero M.J. 2000: Assessing the consequences of global change for forest disturbance from herbivores and pathogens. Science of the Total Environment 262(3): 263-286. DOI: 10.1016/S00489697(00)00528-3

Baker R., Caffier D., Choiseul J.W., Clercq P.De., Gerowitt B., Karadjova O.E., et al. 2009: Evaluation of a pest risk analysis on Thaumetopoea processionea L., the oak processionary moth, prepared by the UK and extension of its scope to the EU territory. The EFSA Journal 1195: 1-64. DOI: 10.2903/j.efsa.2009.1195

Battisti A. \& Larsson S. 2015: Climate change and insect pest distribution range. In: Björkman C. \& Niemelä P. (eds): Climate change and insect pests. Wallingford: CABI, 1-15. DOI: 10.1079/9781780643786.0001

Battisti A. 2008: Forests and climate change - lessons from insects. iForest - Biogeosciences and Forestry 1(1): 1-5. DOI: 10.3832/ifor0210-0010001

Battisti A., Larsson S. \& Roques A. 2017: Processionary moths and associated urtication risk: global changedriven effects. Annual Review of Entomology 62: 323-342. DOI: 10.1146/annurev-ento-031616-034918

Bernardinelli I. \& Zandigiacomo P. 2000: Prima segnalazione di Corythucha arcuata (Say) (Heteroptera, Tingidae) in Europa. Informatore Fitopatologico 50(12): 47-49. 
Blaik T., Malkiewicz A. \& Wasala R. 2011: Rediscovery and remarks on occurrence of Thaumetopoea processionea (Linnaeus, 1758) (Lepidoptera: Notodontidae: Thaumetopoeinae) in Poland. Wiadomości Entomologiczne 30(4): 246-256.

Bognár S. \& Huzián L. 1979: Növényvédelmi állattan. Mezőgazdasági Kiadó, Budapest, 170-182.

Csepelényi M., Hirka A., Mikó Á., Szalai Á. \& Csóka Gy. 2017a: A tölgy-csipkéspoloska (Corythucha arcuata) 2016/2017-es áttelelése Délkelet-Magyarországon. Növényvédelem 53(7): 285-288.

Csepelényi M., Hirka A., Szénási Á., Mikó Á., Szőcs L. \& Csóka Gy. 2017b: Az inváziós tölgycsipkéspoloska [Corythucha arcuata (Say, 1832)] gyors terjeszkedése és tömeges fellépése Magyarországon. Erdészettudományi Közlemények 7(2): 127-134. DOI: 10.17164/ek.2017.009

Csóka Gy., Hirka A., Szőcs L., Móricz N., Rasztovits E. \& Pödör Z. 2018: Weather-dependent fluctuations of Oak Processionary Moth (Thaumetopoea processionea L.) populations. European Journal of Entomology 115: 249-255. DOI: 10.14411/eje.2018.024

Csóka Gy. 1996: Aszályos évek - fokozódó rovarkárok erdeinkben. Növényvédelem 32: 545-551.

Csóka Gy. 2001: Recent invasions of five species of leafmining lepidoptera in Hungary. Proceedings „Integrated Management of Forest Defoliating Insects". USDA General Technical Reports NE-277, 31-36.

Csóka Gy. 2016: A gyapottok bagolylepke (Helicoverpa armigera) terjedése Magyarországon. In: Riesz L. (ed): Magyarország környezeti állapota 2015. HOI, 62-64.

Csóka Gy. \& Hirka A. 2009: A gyapjaslepke (Lymantria dispar L.) legutóbbi tömegszaporodása Magyarországon. Növényvédelem 45(4): 196-201.

Csóka Gy., Hirka A. \& Somlyai M. 2013: A tölgycsipkéspoloska (Corythucha arcuata Say, 1832 - Hemiptera, Tingidae) első észlelése Magyarországon. Növényvédelem 49(7): 293-296.

Csóka Gy., Hirka A. \& Szőcs L. 2012: Rovarglobalizáció a magyar erdőkben. Erdészettudományi Közlemények 2: 187-198.

Csóka Gy. 1997: Increased insect damage in Hungarian forests under drought impact. Biologia 52(2): 159162.

Csóka Gy., Pödör Z., Nagy Gy. \& Hirka A. 2015: Canopy recovery of pedunculate oak, Turkey oak and beech trees after severe defoliation by gypsy moth (Lymantria dispar): Case study from Western Hungary. Forestry Journal 61: 143-148. DOI: 10.1515/forj-2015-0022

Dobbertin M., Wermelinger B., Bigler C., Bürgi M., Carron M., Forster B., et al. 2007: Linking increasing drought stress to scots pine mortality and bark beetle infestations. The Scientific World Journal 7(1): 231-239. DOI: 10.1100/tsw.2007.58

Dobreva M., Simov N., Georgiev G., Mirchev P. \& Georgieva M. 2013: First record of Corythucha arcuata (Say) (Heteroptera: Tingidae) on the Balkan Peninsula. Acta Zoologica Bulgaria 65(3): 409-412.

Endrődi S. 1956: Lemezescsápú bogarak Lamellicornia. In: Szélessy V. et al. (eds): Magyarország Állatvilága Fauna Hungariae IX. kötet, Coleoptera IV. 4. füzet, 106-188.

Forster B., Giacalone I., Moretti M., Dioli P. \& Wermelinger B. 2005: Die amerikanische Eichennetzwanze Corythucha arcuata (Say) (Heteroptera, Tingidae) hat die Südschweiz erreicht. Mitteilungen der Schweizerischen Entomologischen Gesellschaft 78(3-4): 317-323.

Gray D.R., Ravlin W.F., Régnière J. \& Logan J.A. 1995: Further Advances Toward a Model of Gypsy Moth (Lymantria dispar (L.)) Egg Phenology: Respiration Rates and Thermal Responsiveness During Diapause, and Age-dependent Developmental Rates in Postdiapause. Journal of Insect Physiology 41: 247-256. DOI: 10.1016/0022-1910(94)00102-m

Gray D.R., Ravlin F.W. \& Braine J.A. 2001: Diapause in the gypsy moth: a model of inhibition and development. Journal of Insect Physiology 47: 173-184. DOI: 10.1016/s0022-1910(00)00103-7 
Gray D.R. 2004: The gypsy moth life stage model: landscape-wide estimates of gypsy moth establishment using a multi-generational phenology model. Ecological Modelling 176: 155-171. DOI: 10.1016/j.ecolmodel.2003.11.010

Groenen F. \& Meurisse N. 2012: Historical distribution of the oak processionary moth Thaumetopoea processionea in Europe suggests recolonization instead of expansion. Agricultural and Forest Entomology 14(2): 147-155. DOI: 10.1111/j.1461-9563.2011.00552.x

Groenen F. 2010: Variation of Thaumetopoea processionea (Notodontidae: Thaumetopoeinae) in Europe and the Middle East. Entomologische Berichten 70(3): 77-82.

Győrfi J. 1950: Szúkárositások a hazai Lucfevesekben. Agrártudományi Egyetem Erdőmérnöki Karának Évkönyve, 383-394.

Győrfi J. 1954: A cserebogár-kérdés jelenlegi helyzete. Az Erdő 3(1-2): 24-33.

Győrfi J. 1963: Erdővédelemtan. Akadémiai Kiadó, Budapest.

Hirka A. \& Csóka Gy. 2010: Kevésbé ismert lombfogyasztó rovarok tömeges megjelenése hazai nemesnyár ültetvényeken. Növényvédelem 46(11): 529-531.

Hirka A. (ed) 2012: A 2011. évi biotikus és abiotikus erdőgazdasági károk, valamint a 2012-ben várható károsítások. Erdészeti Tudományos Intézet Erdővédelmi Osztály, Mátrafüred.

Hirka A., Csóka Gy. \& Szőcs L. 2011: Long term population trends of some forest pests in Hungary. In: Delb H. \& Pontuali S. (eds): Biotic Risks and Climate Change in Forests, Proceedings of the $10^{\text {th }}$ IUFRO Workshop of WP 7.03.10 „Methodology of Forest Insect and Disease Survey in Central Europe”, September 2023, 2010, Freiburg, Germany, 163-165.

Hlásny T. \& Turčáni M. 2008: Insect pests as climate change driven disturbances in forest ecosystems. In: Střelcová K. et al. (eds) Bioclimatology and Natural Hazards. Springer, Dordrecht, 165-177. DOl: 10.1007/978-1-4020-8876-6_15

Hlásny T., Trombik J., Holuša J., Lukášová K., Grendár M., Turčáni M., et al. 2015: Multi-decade patterns of gypsy moth fluctuations in the Carpathian Mountains and options for outbreak forecasting. Journal of Pest Science 89(2): 413-425. DOI: 10.1007/s10340-015-0694-7

Hoch G., Toffolo E.P., Netherer S., Battisti A. \& Schopf A. 2009: Survival at low temperature of larvae of the pine processionary moth Thaumetopoea pityocampa from an area of range expansion. Agricultural and Forest Entomology 11(3): 313-320. DOI: 10.1111/j.1461-9563.2009.00431.x

Homonnay F. 1973: A májusi cserebogár (Melolontha melolontha L.) törzsek hazai elhelyezkedése, térhódítása és keveredése. A növényvédelem korszerüsitése 7: 31-41.

Homonnay F. 1977: A fénycsapdák alkalmazásának jelentősége a Melolontha fajok rajzásának, ivararányának és tömegszaporodásának kutatásában. Növényvédelem 13(4): 152-159.

Hrašovec B., Posarić D., Lukić I. \& Pernek M. 2013: Prvi nalaz hrastove mrežaste stjenice (Corythucha arcuata) u Hrvatskoj. Šumarski list 137(9-10): 499-503.

Jactel H., Petit J., Desprez-Loustau M.L., Delzon S., Piou D., Battisti A., et al. 2012: Drought effects on damage by forest insects and pathogens: a meta-analysis. Global Change Biology 18(1): 267-276. DOI: 10.1111/j.1365-2486.2011.02512.x

Janik G., Tóth J., Csóka Gy., Szabóky Cs., Hirka A. \& Koltay A. 2008: Az erdészeti jelentőségű cserebogarak életmódja. Az Erdészeti kutatások digitális, ünnepi különszáma az OEE 139. Vándorgyűlésének tiszteletére. Cikkgyüjtemény: 350-380.

Jeffs C.T. \& Lewis O.T. 2013: Effects of climate warming on host-parasitoid interactions. Ecological Entomology 38(3): 209-218. DOI: 10.1111/een.12026

Jepsen J.U., Hagen S.B., Ims R.A. \& Yoccoz N.G. 2008: Climate change and outbreaks of the geometrids Operophtera brumata and Epirrita autumnata in subarctic birch forest: evidence of a recent outbreak range expansion. Journal of Animal Ecology 77(2): 257-264. DOI: 10.1111/j.1365-2656.2007.01339.x 
Jönsson A.M., Appelberg G., Harding S. \& Bärring L. 2009: Spatio-temporal impact of climate change on the activity and voltinism of the spruce bark beetle, Ips typographus. Global Change Biology 15(2): 486-499. DOI: 10.1111/j.1365-2486.2008.01742.x

Jurásek F. \& Román J. 1997: A „Soproni fenyveserdő” végnapjai ...? Erdészeti Lapok 132(10): 313-315.

Kalinkat G. \& Rall B.C. 2015: Effects of climate change on the interactions between insect pests and their natural enemies. In: Björkman C. \& Niemala P. (eds): Climate change and insect pests. Wallingford: $\mathrm{CABI}$, 74-91. DOI: 10.1079/9781780643786.0074

Keszthelyi S., Nowinszky L., \& Puskás J. 2013: The growing abundance of Helicoverpa armigera in Hungary and its areal shift estimation. Open Life Sciences 8(8): 756-764. DOI: 10.2478/s11535-013-0195-0

Klapwijk M.J., Csóka Gy., Hirka A. \& Björkman C. 2013: Forest insects and climate change: long-term trends in herbivore damage. Ecology and Evolution 3(12): 4183-4196. DOI: 10.1002/ece3.717

Lakatos F. 1997: Szúkárositások alakulása a Soproni-hegyvidéken. Erdészeti Lapok 132(10): 325-326.

Lakatos F. \& Molnár M. 2009: Mass mortality of beech (Fagus sylvatica L.) in South-West Hungary. Acta Silvatica et Lignaria Hungarica 5: 75-82.

Leskó K. \& Szabóky Cs. 2003: Új károsító az akácon a gyapottok bagolylepke (Helicoverpa armigera Hübner, 1808). Erdészeti Lapok 138(3): 96-97.

Leskó K., Szentkirályi F. \& Kádár F. 1995: Long term fluctuation pattern of the brown -tale moth (Euproctis chrysorrhoea L.) Hungarian population. Erdészeti Kutatások 85: 169-185.

Leskó K., Szentkirályi F. \& Kádár F. 1998: An analysis of fluctuation pattern of geometrid moths based on long term (1961-1997) light trap and damage data time series in Hungary. Erdészeti Kutatások 88: 319-333.

Lövgren R. \& Dalsved B. 2005: Thaumetopoea processionea L. (Lepidoptera: Thaumetopoeidae) found in Sweden. Entomologisk Tidskrift 126(1-2): 93-94.

Marini L., Økland B., Jönsson A.M., Bentz B., Carroll A., Forster B., et al. 2017: Climate drivers of bark beetle outbreak dynamics in Norway spruce forests. Ecography 40: 1426-1435. DOI: 10.1111/ecog.02769

Mattson W.J. \& Haack R.A. 1987: Role of Drought in Outbreaks of Plant-Eating Insects The role of drought in outbreaks of plant-eating insects drought's physiological effects on plants can predict its influence on insect populations. Bioscience 37(2): 110-118. DOI: 10.2307/1310365

Mindlin M.J., Polain O., Waroux D., Case S. \& Walsh B. 2012: The arrival of oak processionary moth, a novel cause of itchy dermatitis, in the UK : Experience, lessons and recommendations. Public Health 126(9): 778-781. DOI: 10.1016/j.puhe.2012.06.007

Mirchev P., Georgiev G., Georgieva M. \& Bocheva L. 2016: Impact of low temperatures on pine processionary moth (Thaumetopoea pityocampa) larval survival in Bulgaria. Silva Balcanica 17(1): 51-58.

Molnár M., Brück-Dyckhoff C., Petercord R. \& Lakatos F. 2010: A zöld karcsúdíszbogár (Agrilus viridis L.) szerepe a bükkösök pusztulásában. Növényvédelem 46(11): 522-528.

Mutun S. 2003: First report of the oak lace bug, Corythucha arcuata (Say, 1832) (Heteroptera: Tingidae) from Bolu, Turkey. Israel Journal of Zoology 49: 323-324.

Netherer S., Matthews B., Katzensteiner K., Blackwell E., Henschke P., Hietz P., et al. 2015: Do water-limiting conditions predispose Norway spruce to bark beetle attack? The New Phytologist 205(3): 1128-1141. DOI: 10.1111/nph.13166

Nowinszky L. \& Nagy L. 1977: Új matematikai módszer a májusi cserebogár (Melolontha melolontha L.) rajzáskezdetének kiszámítására. Növényvédelem 13(8): 337-340.

Pelini S.L., Prior K.M., Parker D.J., Dzurisin J.D.K., Lindroth R.L. \& Hellmann J.J. 2009: Climate Change and Temporal and Spatial Mismatches in Insect Communities. In: Letcher T.M. (ed): Climate Change (1 ${ }^{\text {st }}$ ed.). Elsevier, Amsterdam, 215-231. DOI: 10.1016/B978-0-444-53301-2.00011-7 
Pimentel C., Calvão T. \& Ayres M.P. 2011: Impact of climatic variation on populations of pine processionary moth Thaumetopoea pityocampa in a core area of its distribution. Agricultural and Forest Entomology 13(3): 273-281. DOI: 10.1111/j.1461-9563.2011.00520.x

Pimentel C., Calvão T., Santos M., Ferreira C., Neves M. \& Nilsson J.Å. 2006: Establishment and expansion of a Thaumetopoea pityocampa (Den. \& Schiff.) (Lep. Notodontidae) population with a shifted life cycle in a production pine forest, Central-Coastal Portugal. Forest Ecology and Management 233(1): 108-115. DOI: 10.1016/j.foreco.2006.06.005

Ponomarev V.I., Benkovskaya G.V. \& Klobukov G.I. 2014: Effect of Heat Stress on Morphophysiological Characteristics and Biochemical Parameters of Stress Response in Gypsy Moth (Lymantria dispar L.) Larvae. Russian Journal of Ecology 45(4): 275-281. DOI: 10.1134/s1067413614040080

Pureswaran D.S., Roques A. \& Battisti A. 2018: Forest Insects and Climate Change. Current Forestry Reports 4(2): 35-50. DOI: 10.1007/s40725-018-0075-6

Robinet C. \& Roques A. 2010: Direct impacts of recent climate warming on insect populations. Integrative Zoology 5(2): 132-142. DOI: 10.1111/j.1749-4877.2010.00196.x

Roth M. 2003: Szúgradáció kialakulásának feltételei és lefolyása a Soproni-hegységben 1987-2001. Erdészeti Lapok 138(12): 356-358.

Roques A., Rousselet J., Avci M., Avtzis D.N., Basso A., Battisti A., et al. 2015: Climate warming and past and present distribution of the processionary moths (Thaumetopoea spp.) in Europe, Asia Minor and North Africa. In: Roques A. (ed): Processionary moths and climate change : an update. Springer Netherlands, Dordrecht, 22: 81-161. DOI: 10.1007/978-94-017-9340-7_3

Rouault G., Candau J-N., Lieutier F., Nageleisen L-M., Martin J-C. \& Warzée N. 2006: Effects of drought and heat on forest insect populations in relation to the 2003 drought in Western Europe. Annals of Forest Science 63(6): 613-624. DOI: 10.1051/forest:2006044

Sawyer A.J., Tauber M.J., Tauber C.A. \& Ruberson J.R. 1993: Gypsy moth (Lepidoptera: Lymantriidae) egg development: a simulation analysis of laboratory and field data. Ecological Modelling 66: 121-155. DOI: 10.1016/0304-3800(93)90043-r

Sparks T.H., Roy D.B. \& Dennis R.L.H. 2005: The influence of temperature on migration of Lepidoptera into Britain. Global Change Biology 11(3): 507-514. DOI: 10.1111/j.1365-2486.2005.00910.x

Stigter H. \& Romeijn G. 1992: Thaumetopoea processionea na ruim een eeuw weer plaatselijk massaal in Nederland (Lepidoptera: Thaumetopoeidae). Entomologische berichten 55: 66-69.

Straw N.A. \& Williams D.T. 2013: Impact of the leaf miner Cameraria ohridella (Lepidoptera: Gracillariidae) and bleeding canker disease on horse-chestnut: Direct effects and interaction. Agricultural and Forest Entomology 15: 321-333. DOI: 10.1111/afe.12020

Szabóky Cs., \& Szentkirályi F. 1995: A gyapottok-bagolylepke (Helicoverpa armigera Hübner, 1808) szezonalitása az erdészeti fénycsapdák gyüjtései alapján. Növényvédelem 31(6): 267-274.

Szeőke K. \& Csóka Gy. 2012: Jövevény kártevő ízeltlábúak Magyarországon - Lepkék (Lepidoptera). Növényvédelem 48(3): 105-115.

Szép T. 2005: Szúkárosítás a Szombathelyi Erdészeti Rt. területén. Erdészeti Lapok 140(12): 351-353.

Szép T. 2008: Vas megye lucfenyő nélkül? Erdészeti Lapok 143(4): 120-121.

Szőcs L., Gimesi L., Hirka A., \& Csóka Gy. 2018: Trendek a gyapottok bagolylepke (Helicoverpa armigera) magyarországi populációs fluktuációiban és rajzásfenológiájában. Kézirat.

Tóth L. 1976: A májusi cserebogár (Melolontha melolontha L.) rajzáskezdet-előrejelzési lehetőségeinek vizsgálata. Növényvédelem 12(5): 221-222.

Tuba K., Horváth B. \& Lakatos F. 2012: Inváziós rovarok fás növényeken. Nyugat-magyarországi Egyetem Kiadó, Sopron. 
Turcani M., Csóka Gy., Grodzki W. \& Zahradnik P. 2001: Recent invasions of forest insect pests in Central Europe. Protection of World Forests from Insect Pests: Advances in Research. Papers presented at the XXI IUFRO World Congress 7-12 August 2000, Kuala Lumpur, Malaysia. IUFRO World Series Vol. 11. 99 104.

Vanhanen H., Veteli T.O., Paivinen S., Kellomaki S. \& Niemela P. 2007: Climate change and range shifts in two insect defoliators: gypsy moth and nun moth - a model study. Silva Fennica 41(4): 621-638. DOI: $10.14214 / s f .469$

Wagenhoff E. \& Veit H. 2011: Five years of continuous Thaumetopoea processionea monitoring: tracing population dynamics in an arable landscape of South-Western Germany. Gesunde Pflanzen 63(2): 51-61. DOI: $10.1007 / s 10343-011-0244-z$

Wagenhoff E., Blum R., Engel K., Veit H. \& Delb H. 2013: Temporal synchrony of Thaumetopoea processionea egg hatch and Quercus robur budburst. Journal of Pest Science 86(2): 193-202. DOI: 10.1007/s10340012-0457-7

Wagenhoff E., Wagenhoff A., Blum R., Veit H., Zapf D. \& Delb H. 2014: Does the prediction of the time of egg hatch of Thaumetopoea processionea (Lepidoptera: Notodontidae) using a frost day/temperature sum model provide evidence of an increasing temporal mismatch between the time of egg hatch and that of budburst of Quercus. European Journal of Entomology 111(2): 207-215. DOI: 10.14411/eje.2014.030

\section{On-line irodalom}

Skule B. \& Vilhelmsen F. 1997: Thaumetopoea processionea L. found in Denmark. Available from http://www.lepidoptera.dk/process.htm Letöltve: 2017.05.30.

Érkezett: 2018. május 1.

Közlésre elfogadva: 2018. május 30. 